\title{
Long-term oral administration of cows' milk improves insulin sensitivity in rats fed a high-sucrose diet
}

\author{
Megumi Matsumoto ${ }^{1}$, Ryo Inoue ${ }^{1}$, Takeshi Tsuruta ${ }^{2}$, Hiroshi Hara ${ }^{2}$ and Takaji Yajima ${ }^{1}$ \\ ${ }^{1}$ Meiji Dairies Research Chair, Creative Research Initiative Sousei (CRIS), Hokkaido University, Kita-21, Nishi-10, Kita-ku, \\ Sapporo, Hokkaido 001-0021, Japan \\ ${ }^{2}$ Division of Applied Bioscience, Laboratory of Nutritional Biochemistry, Graduate School of Agriculture, Hokkaido University, \\ Kita-9, Nishi-9, Kita-ku, Sapporo, Hokkaido 060-8589, Japan
}

(Received 20 October 2008 - Revised 23 March 2009 - Accepted 30 April 2009 - First published online 1 July 2009)

We evaluated the effects of long-term daily cows' milk (CM) administration on insulin resistance induced by a high-sucrose diet. F344 rats, aged 3 weeks, were divided into two groups according to diet (dextrin-fed $v$. sucrose-fed). These groups were further divided into two groups receiving either CM or artificial milk (AM; isoenergetic emulsion of egg white protein, maltose, lard and minerals). Rats were fed a sucrose- or dextrin-based diet for 7 weeks and orally administered CM or AM at $25 \mathrm{ml} / \mathrm{kg}$ following an $8 \mathrm{~h}$ fast on a daily basis. Insulin sensitivity was evaluated via postprandial changes in serum glucose and insulin, oral glucose tolerance tests, and fasting serum insulin and fructosamine concentrations. The sucrose-fed rats showed an overall decrease in insulin sensitivity, but postprandial insulin levels were lower in the CM-treated subgroup than in the AM-treated subgroup. Peak serum glucose and insulin concentrations were highest in the sucrose-fed rats, but CM administration reduced peak glucose and insulin values in comparison with AM administration. By area under the curve analysis, insulin levels after feeding and glucose loads were significantly lower in the CM-treated groups than in the AM-treated groups. The CM-treated groups also demonstrated lower fasting insulin and fructosamine levels than the AM-treated groups. Improved insulin sensitivity due to CM administration seemed to be associated with reduced duodenal GLUT2 mRNA levels and increased propionate production within the caecum.

Cows' milk: Insulin sensitivity: Intestinal microbiota: Rats

Humans have been ingesting cows' milk (CM) and related products (i.e. cheese and butter) over the course of many millennia. In 2003, the worldwide consumption of CM and related products was estimated to be approximately half a million tons, which corresponds to approximately $81 \mathrm{~kg}$ per capita per year $^{(1)}$. Despite this massive consumption of $\mathrm{CM}$, the physiological effects of this nutrient and energy resource have not been fully elucidated.

Over the previous decade, several studies have examined the effects of CM and its products on human obesity, diabetes and the risk of the metabolic syndrome. These studies revealed inverse relationships between dairy product consumption and body weight, blood glucose levels and blood pressure ${ }^{(2-8)}$. Studies using animal models have also demonstrated the beneficial effects of skimmed milk and whey protein against the metabolic syndrome ${ }^{(9,10)}$. In mice, a diet containing skimmed milk reduced body-weight gain in comparison with a normal $\operatorname{diet}^{(11)}$, and in rats a whey protein-based diet had positive effects on insulin resistance ${ }^{(12)}$. In these animal studies, however, very high amounts of milk and/or its components were included in the test diets. Approximately 5-10 litres $\mathrm{CM} /$ person per $\mathrm{d}$ should be ingested to be equivalent to the amount of milk and/or its components used in most of the animal studies. Additionally, skimmed milk and whey protein were replaced with alternative ingredients. These considerations raise questions regarding the results of previous studies and the true effects of $\mathrm{CM}$ on insulin resistance.

We made a hypothesis that such a high amount of milk and/or its components may not be necessary to have a beneficial effect on insulin resistance even in animal models. We also hypothesised that a supplementation of CM to the daily diet is presumably a more suitable animal experimental model than the replacement of the main ingredients of the diet with CM components, since CM is normally ingested not as an essential nutrient component but as a supplement in humans.

Our aim was to determine whether the beneficial effects of $\mathrm{CM}$ on reduced insulin sensitivity are experimentally reproducible using normal doses of $\mathrm{CM}$ in rats. In addition, we designed our experiments to mimic a human pattern of milk consumption (i.e. drinking milk before breakfast every day). Insulin resistance was assessed because this parameter is strongly associated with the metabolic syndrome ${ }^{(13,14)}$. We examined the effects of $\mathrm{CM}$ on insulin sensitivity compared with artificial milk (AM), an emulsion with the

Abbreviations: AM, artificial milk; AUC, area under the curve; CM, cows' milk; D, dextrin; OGTT, oral glucose tolerance test; S, sucrose; SGLT1, Na ${ }^{+}$-dependent GLUT1; T-RFLP, terminal-restriction fragment length polymorphism.

*Corresponding author: Dr Megumi Matsumoto, fax +81 11706 9220, email matsumeg@cris.hokudai.ac.jp 
same energetic and nutritional composition as CM. Rats fed a high-sucrose (S) diet to induce insulin resistance were compared with control rats fed a dextrin (D)-based diet ${ }^{(15,16)}$. To gain insight into the molecular mechanism(s) responsible for the beneficial effects of milk consumption, we also examined the mRNA expression of the $\mathrm{Na}^{+}$-dependent glucose transporter (SGLT1), glucose transporter type 2 (GLUT2) and proglucagon in the small intestine, and analysed changes in caecal microbiota and SCFA composition. It was previously reported that glucose absorption increased in patients with obesity and diabetes ${ }^{(17,18)}$. Furthermore, these changes were accompanied by the increased expression of GLUT, including SGLT1 and GLUT2, in the intestinal brush-border membrane ${ }^{(19-21)}$. Diabetic therapy based on incretins such as proglucagon, which is processed to yield the insulin secretion-enhancing glucagon-like peptide-1, has been the focus of a number of recent studies ${ }^{(22,23)}$. In addition, the role of gut microbial metabolism in the metabolic syndrome has been demonstrated in both human subjects and experimental animals ${ }^{(24-27)}$. In particular, SCFA, which are the endproducts of bacterial fermentation in the intestine, may have an impact on insulin resistance ${ }^{(28)}$.

\section{Materials and methods}

\section{Animals and diets}

Male F344 rats (Japan SLC, Shizuoka, Japan) aged 3 weeks and weighing approximately $50 \mathrm{~g}$ were individually housed in stainless-steel cages with wire-mesh bottoms. The cages were placed in a room with controlled temperature $\left(22-24^{\circ} \mathrm{C}\right)$, relative humidity $(40-60 \%)$ and lighting (lights on from 05.00 to 17.00 hours). The rats were allowed ad libitum access to deionised water and a semi-purified diet based on the American Institute of Nutrition AIN-93G formulation $^{(29)}$, for an acclimatisation period of $3 \mathrm{~d}$. The Hokkaido University Animal Committee approved the study and all animals were maintained in accordance with the Hokkaido University guidelines for the care and use of laboratory animals.

\section{Preparation of test milk emulsion}

Commercially available CM was obtained from Meiji Dairies Co. Ltd (Tokyo, Japan). AM emulsions were prepared using a high-pressure homogeniser (Gaulin 15MR-8TBA; APV Gaulin Inc., Wilmington, MA, USA) ${ }^{(30)}$. The AM formula had the same energetic and nutritional composition as CM (Table 1) ${ }^{(31-34)}$. The AM was composed of general nonmilk-related food materials to replace the components of milk. Lactose, milk protein and milk lipid were replaced by maltose, egg white protein and lard, respectively. Chemically synthesised reagents were used as a mineral source in AM.

\section{Study design}

Following the acclimatisation period, the rats were divided into four groups, each consisting of six rats. Two groups were fed the $\mathrm{D}$ diet and two groups were fed the $\mathrm{S}$ diet for 7 weeks. The diet compositions are listed in Table 2 . On each day throughout the experimental period, access
Table 1. Composition of artificial milk (AM) and cows' milk (CM) $(\mathrm{g} / \mathrm{kg})$

\begin{tabular}{|c|c|c|}
\hline & AM & $\mathrm{CM}$ \\
\hline \multicolumn{3}{|l|}{ Protein } \\
\hline Casein & - & 2.72 \\
\hline Whey & - & 0.65 \\
\hline Other* & - & 0.03 \\
\hline Egg white protein $†$ & 3.40 & - \\
\hline \multicolumn{3}{|l|}{ Carbohydrate } \\
\hline Lactose & - & 4.90 \\
\hline Maltoseł & 4.95 & - \\
\hline Oligosaccharides§ & - & 0.05 \\
\hline \multicolumn{3}{|l|}{ Lipid } \\
\hline Milk lipid\| & - & 3.90 \\
\hline Lard $\|$ & 3.90 & - \\
\hline $\mathrm{K}^{\star \star}$ & 0.15 & 0.15 \\
\hline Ca†t & 0.11 & 0.11 \\
\hline Mgł‡ & 0.01 & 0.01 \\
\hline P§§ & 0.09 & 0.09 \\
\hline $\mathrm{Nall \|}$ & 0.07 & 0.07 \\
\hline \\
\hline \multirow{2}{*}{\multicolumn{3}{|c|}{$\begin{array}{l}\text { †Processed Egg (Taiyo Kagaku Co. Ltd, Mie, Japan). } \\
\text { ¥ Wako Pure Chemical Industries, Ltd, Osaka, Japan. }\end{array}$}} \\
\hline & & \\
\hline \multicolumn{3}{|c|}{$\begin{array}{l}\text { §S See Gopal \& Gill(33). } \\
\text { || See Christie }\end{array}$} \\
\hline \multirow{2}{*}{\multicolumn{3}{|c|}{$\begin{array}{l}\text { I Snow Brand Milk Products Co., Ltd, Sapporo, Japan. } \\
\text { ** Potassium sulfate (Wako Pure Chemical Industries, Ltd, Osaka, } \\
\text { Japan). }\end{array}$}} \\
\hline & & \\
\hline \multicolumn{3}{|c|}{$\begin{array}{l}\text { †† Calcium carbonate (Wako Pure Chemical Industries, Ltd, Osaka, } \\
\text { Japan). }\end{array}$} \\
\hline \multicolumn{3}{|l|}{$\begin{array}{l}\text { 㧊 Magnesium oxide (Wako } \\
\text { Japan). }\end{array}$} \\
\hline \multicolumn{3}{|c|}{$\begin{array}{l}\text { §S Sodium dihydrogen phosphate dehydrate (Nacalai Tesque Inc., } \\
\text { Kyoto, Japan). }\end{array}$} \\
\hline \multicolumn{3}{|c|}{$\begin{array}{l}|\|| \mid \text { Content of } \mathrm{Na} \text { in } \mathrm{AM} \text { was that estimated from the source of } \mathrm{P} \\
\text { (sodium dihydrogen phosphate dehydrate). }\end{array}$} \\
\hline
\end{tabular}

to the diet was restricted from 17.00 until 09.00 hours the following morning; thus, $8 \mathrm{~h}$ food deprivation was imposed per d. Within each diet assignment, one of the two groups was orally administered $25 \mathrm{ml}$ (approximately $8 \%$ of total energy intake) of CM (D-CM and S-CM groups) per $\mathrm{kg}$ body weight; the remaining two groups were administered the same amount of AM (D-AM and S-AM groups) via a feeding tube $(35 \mathrm{~cm}$; TERUMO, Tokyo, Japan) at 17.00 hours.

Table 2. Experimental diet composition ( $\mathrm{g} / \mathrm{kg}$ diet)

\begin{tabular}{|c|c|c|}
\hline & Dextrin & Sucrose \\
\hline Casein* & $200 \cdot 0$ & $200 \cdot 0$ \\
\hline Dextrin $†$ & 629.5 & - \\
\hline Sucroseł & - & 629.5 \\
\hline Lard§ & 70.0 & $70 \cdot 0$ \\
\hline Mineral mixture\| & 35.0 & 35.0 \\
\hline Vitamin mixture\| & $10 \cdot 0$ & $10 \cdot 0$ \\
\hline Choline chlorideq & 2.5 & 2.5 \\
\hline L-Cystine & $3 \cdot 0$ & 3.0 \\
\hline Cellulose $^{\star \star}$ & $50 \cdot 0$ & $50 \cdot 0$ \\
\hline
\end{tabular}

*ALACID (New Zealand Daily Board, Wellington, New Zealand). †TK-16 (Matsutani Chemical Industry Co., Ltd, Hyogo, Japan). $\ddagger$ Sucrose (Nippon Beet Sugar Manufacturing Co., Ltd, Obihiro, Japan).

$\S$ Lard (Snow Brand Milk Products Co., Ltd, Sapporo, Japan). $\|$ Mineral and vitamin mixtures were prepared according to the AIN-93G formulation ${ }^{(29)}$ (CLEA Japan, Inc., Tokyo, Japan).

I Wako Pure Chemical Industries, Ltd, Osaka, Japan.

${ }^{\star *}$ Cellulose powder (JustFiber; Morimura Bros., Inc., Tokyo, Japan). 
The test diet was made available immediately after the test milk administration. Body weight and food intake were measured daily. Blood samples were collected at days 42 and 45 .

On the last day of the 7-week experimental period, all rats were anaesthetised with sodium pentobarbital between 09.00 and 11.00 hours. The abdominal cavity was opened, abdominal aortic blood was collected, and the rats were euthanised. Segments were taken from the duodenum (below the stomach), jejunum ( $5 \mathrm{~cm}$ distal to the Trietz ligament) and ileum $(5 \mathrm{~cm}$ proximal to the ileocaecal junction). The segments were cut open along the mesenteric border to form flat sheets, rinsed with ice-cold saline $(154 \mathrm{mM}-\mathrm{NaCl})$ and immediately immersed into RNAlater (Sigma, Tokyo, Japan). After $4 \mathrm{~h}$, the serosa and muscle layers of the segments were removed and re-immersed in RNAlater. The samples were then stored at $-80^{\circ} \mathrm{C}$ for subsequent analyses. The caecal tissues and contents were weighed and the contents were stored at $-80^{\circ} \mathrm{C}$ for subsequent analyses.

\section{Measurement of postprandial serum and insulin responses}

On day 42, $100 \mu \mathrm{l}$ of tail blood was collected before the administration of either $\mathrm{CM}$ or $\mathrm{AM}(0 \mathrm{~min})$, and $2 \mathrm{~g}$ of the test diet were made available $30 \mathrm{~min}$ after milk administration. All rats consumed the available food within $10 \mathrm{~min}$. Blood samples were collected 30,60, 90, 150, 210 and $270 \mathrm{~min}$ after milk administration. The blood samples were immediately centrifuged $\left(1300 \mathrm{~g}\right.$ for $15 \mathrm{~min}$ at $\left.4^{\circ} \mathrm{C}\right)$ and sera were stored at $-80^{\circ} \mathrm{C}$. Serum glucose and insulin concentrations were analysed using a glucose test (Wako Pure Chemical Industries, Tokyo, Japan) and a rat insulin ELISA kit (Shibayagi, Gunma, Japan), respectively, according to the manufacturers' instructions.

\section{Oral glucose tolerance test}

On day 45, tail blood samples were collected at 17.00 hours without test milk administration or test diet feeding. A glucose solution $(200 \mathrm{~g} / \mathrm{l})$ was administered via a feeding tube at a dose of $2 \mathrm{~g} / \mathrm{kg}$ body weight. Tail blood was collected again at $15,30,60$ and $120 \mathrm{~min}$ after glucose administration. Serum collection and serum glucose and insulin analysis were carried out as described above.

\section{Serum TAG and fructosamine analyses}

TAG concentrations were determined in serum samples collected at $0 \mathrm{~min}$ during the oral glucose tolerance test (OGTT) using a TAG test (Wako, Tokyo, Japan). Serum samples collected from the abdominal aorta at the end of the experiment were used to determine fructosamine levels. Fructosamine was measuring using a colorimetric assay in which glycated proteins reduce nitroblue tetrazolium (BML, Tokyo, Japan).

\section{Real-time quantitative polymerase chain reaction}

Total RNA extraction and reverse transcription (cDNA synthesis) was performed as described by Inoue et al. ${ }^{(35)}$. Real-time PCR was performed using a 7300 Real-Time PCR System (Applied Biosystems, Tokyo, Japan). The primers and probes (TaqMan Assays-on-Demand Gene Expression Products) were designed at Biosearch Technologies, Inc. (Tokyo, Japan) from gene sequences obtained from GenBank (proglucagon, NM-017077; glucoamylase, XM231714; isomaltase-sucrase complex, NM-013061; lactase, XM-341115; SGLT1, NM-013033; GLUT2, NM-012879). Amplification was carried out in a $10 \mu \mathrm{l}$ reaction volume containing $5 \mu \mathrm{l}$ of Premix Ex $\mathrm{Taq}^{\mathrm{TM}}$ (Perfect Real Time; TaKaRa Bio Inc., Shiga, Japan), $0.4 \mu \mathrm{l}$ cDNA, $0.9 \mathrm{mmol} / \mathrm{l}$ of each primer, and $0.25 \mathrm{mmol} / \mathrm{l}$ of Taqman probe. The thermal cycling profile was $10 \mathrm{~s}$ at $95^{\circ} \mathrm{C}$ followed by forty cycles of $5 \mathrm{~s}$ at $95^{\circ} \mathrm{C}$ and $34 \mathrm{~s}$ at $60^{\circ} \mathrm{C}$. The $\beta$-actin gene was amplified as a housekeeping gene; however, SYBR Premix Ex Taq ${ }^{\mathrm{TM}}$ (Perfect Real Time; TaKaRa Bio Inc.) was used instead of Premix Ex $\mathrm{Taq}^{\mathrm{TM}}$. The arbitrary gene expression unit for each sample was calculated as described by Inoue et al. ${ }^{(36)}$.

\section{Terminal-restriction fragment length polymorphism analysis}

Whole bacterial DNA was extracted from caecal contents using the QuickGene DNA Tissue kit SII (Fuji Film, Tokyo, Japan), which is a DNA extraction kit for use with a semiautomated nucleic acid extraction machine (QuickGene810; Fuji Film). PCR was performed using primers homologous for conserved regions on the bacterial $16 \mathrm{~S}$ ribosomal RNA (rRNA) gene: forward primer (27F), 5'-AGA GTT TGA TCC TGG CTC AG-3'; reverse primer (1492R), 5'-GGC TAC CTT GTT ACG ACT T- $3^{\prime}$. The forward primer was fluorescently labelled with Beckman D4 dye (Sigma Genosys, Hokkaido, Japan). Amplification was carried out in a $50 \mu \mathrm{l}$ reaction mixture containing $1 \mu \mathrm{l}$ of DNA template, $5 \mu \mathrm{l}$ of $10 \times$ Ex Taq buffer (TaKaRa Bio Inc.), $0.2 \mathrm{mmol} / \mathrm{l}$ of each deoxynucleoside triphosphate (dNTP), $0.4 \mu \mathrm{mol} / \mathrm{l}$ of each primer and 1.5 units of Ex Taq DNA polymerase (TaKaRa Bio Inc.). The thermal cycling profile was $94^{\circ} \mathrm{C}$ for $10 \mathrm{~min}$, followed by thirty cycles of $94^{\circ} \mathrm{C}$ for $30 \mathrm{~s}, 50^{\circ} \mathrm{C}$ for $30 \mathrm{~s}$, and $72^{\circ} \mathrm{C}$ for $1 \mathrm{~min} 30 \mathrm{~s}$, and a final extension step at $72^{\circ} \mathrm{C}$ for $5 \mathrm{~min}$. All PCR products were purified using a NucleoFast 96 PCR clean-up plate (Machery-Nagel, Düren, Germany) according to the manufacturer's instructions. Single-stranded DNA sections of the 16S rRNA gene amplicon were digested using mung bean nuclease (Promega, Osaka, Japan). The purified PCR product was incubated for $30 \mathrm{~min}$ at $37^{\circ} \mathrm{C}$ with 4 units of mung bean nuclease and the appropriate buffer in a total volume of $100 \mu \mathrm{l}$. After digestion, PCR products were purified using a NucleoFast 96 PCR clean-up plate. The purified products were digested using a restriction enzyme overnight at $37^{\circ} \mathrm{C}$ in a total volume of $20 \mu \mathrm{l}$. Each digest consisted of $17 \mu \mathrm{l}$ of purified PCR product, 10 units of either restriction endonuclease Hha I or Msp I (TaKaRa Bio Inc.) and the appropriate $10 \times$ buffer $(\mathrm{M}$ or $\mathrm{T}$ buffer; TaKaRa Bio Inc.). The digested products were precipitated in ethanol and re-suspended in $24.7 \mu \mathrm{l}$ of sample loading solution (SLS; Beckman Coulter, Tokyo, Japan) and $0.3 \mu l$ of CEQ 600 bp standard (Beckman Coulter). Terminal-restriction fragment length polymorphism (T-RFLP) profiles were obtained using a Beckman Coulter CEQ8000 DNA analysis system, which was equipped with Beckman Coulter CEQ 8000 Genetic Analysis System software (version 9.0 series, product number A16650) ${ }^{(37)}$. 

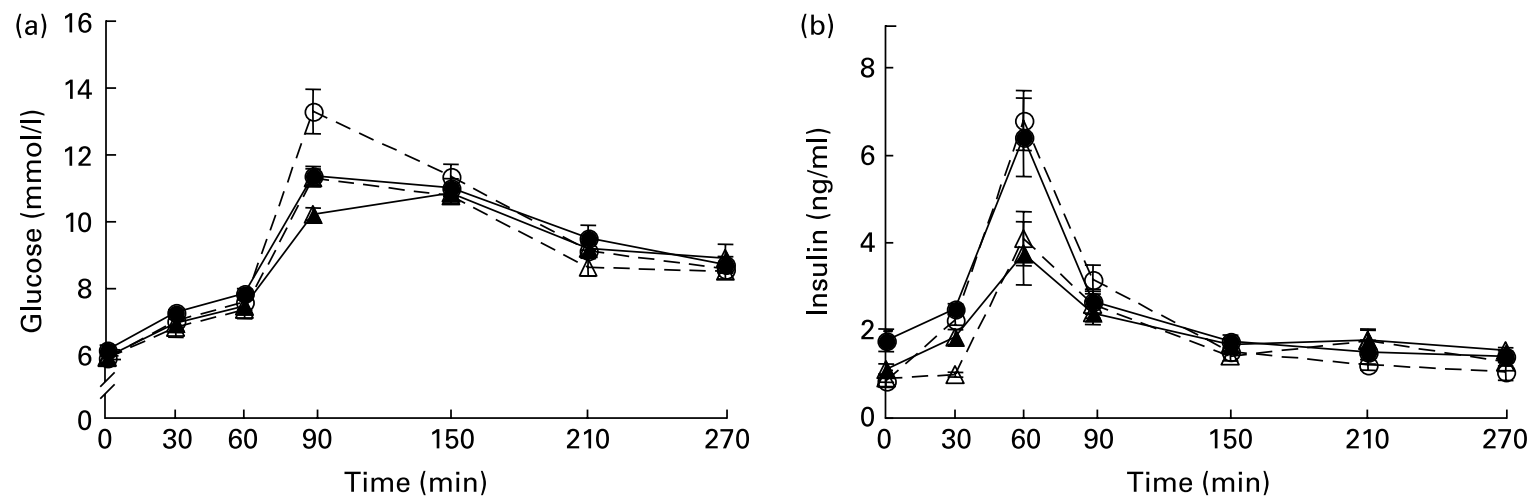

Fig. 1. Changes in postprandial serum glucose (a) and insulin (b) concentrations after oral milk administration ( $5 \mathrm{ml} /$ rat) and subsequent test diet administration $(2 \mathrm{~g} /$ rat $)$ in rats. (--O--), Dextrin-fed, artificial milk administered; (-- $\triangle--)$, dextrin-fed, cows' milk administered; (-๑-), sucrose-fed, artificial milk administered; $(-\mathbf{\Delta}-)$, sucrose-fed, cows' milk administered. Postprandial serum glucose and insulin tolerance tests were performed on day 43 after the start of experimental diet administration. Values are means for six rats per group, with standard errors represented by vertical bars. $P$ values were estimated for peak values via twoway ANOVA: (a) $90 \mathrm{~min}$ blood glucose: diet, $P=0.002$; milk, $P=0.001$; diet $\times$ milk, $P=0.335$; (b) 30 min blood insulin (milk administration after 30 min): diet, $P<0.001$; milk, $P<0.001$; diet $\times$ milk, $P=0.027$; $60 \mathrm{~min}$ (diet fed after $30 \mathrm{~min}$ ): diet, $P=0.620$; milk, $P=0.001$; diet $\times$ milk, $P=0.97$.

\section{Hierarchical clustering analysis of terminal-restriction} fragment length polymorphism profiles

T-RFLP fragment profiles were analysed using the abovementioned fragment-analysis software and all fragment sizes for each profile were exported in comma-separated values (CSV) file format. The data were further analysed using hierarchical clustering analysis with Euclidean square distances using an Excel macro program as described by Inoue et al. ${ }^{(38)}$.

\section{Organic acid analysis}

The concentrations of organic acids (acetic, propionic, butyric, succinic and lactic acid) in homogenates of caecal contents were measured according to the methods described by Shiga et al. ${ }^{(39)}$. Briefly, caecal contents were diluted in four volumes of deionised water and homogenised using a Teflon homogeniser (Iuchi-Seleido, Osaka, Japan). The homogenate was mixed with a $\mathrm{NaOH}$ solution (final concentration of $20.8 \mathrm{mmol} / \mathrm{l})$ containing crotonic acid at a final concentration of $4.17 \mathrm{mmol} / \mathrm{l}$. The mixture was then centrifuged and passed through a filter disk with a pore size of $0 \cdot 2 \mu \mathrm{m}$. Filtered samples were analysed via HPLC using a solvent-delivery system (SLC-10 AVP; Shimadzu, Co. Ltd), a double ion-exchange column (Shim-Pack SCR-102 h, $8 \times 300 \mathrm{~mm}$; Shimadzu) and an electroconductivity detector (CDD-6A; Shimadzu).

\section{Calculations and statistics}

All values are expressed as the mean values with their standard errors. The effects of $\mathrm{CM}$ administration on the area under the curve (AUC) for glucose and insulin levels, blood fructosamine concentrations, and caecal organic acids were analysed using two-way ANOVA. Differences in postprandial and OGTT glucose and insulin levels between the CM- and AM-treated groups during the evaluation period were analysed via two-way ANOVA. A Tukey-Kramer test was used for comparisons among groups. A difference of $P<0.05$ was considered statistically significant. All data were analysed

Table 3. Area under the curve analysis for postprandial serum glucose and insulin concentrations in rats in response to oral milk administration ( $5 \mathrm{ml} / \mathrm{rat})$ and subsequent feeding of each test diet $(2 \mathrm{~g} / \mathrm{rat}) \dagger$

(Mean values with their standard errors for six rats per group)

\begin{tabular}{|c|c|c|c|c|c|c|c|c|c|c|c|c|}
\hline & \multicolumn{6}{|c|}{ Glucose $(\mathrm{mmol} / \mathrm{l})$} & \multicolumn{6}{|c|}{ Insulin (ng/ml) } \\
\hline & \multicolumn{2}{|c|}{$0-150 \mathrm{~min}$} & \multicolumn{2}{|c|}{$0-210 \min$} & \multicolumn{2}{|c|}{$0-270 \mathrm{~min}$} & \multicolumn{2}{|c|}{$0-150 \min$} & \multicolumn{2}{|c|}{$0-210 \min$} & \multicolumn{2}{|c|}{$0-270 \min$} \\
\hline & Mean & SEM & Mean & SEM & Mean & SEM & Mean & SEM & Mean & SEM & Mean & SEM \\
\hline \multicolumn{13}{|l|}{ Dextrin diet } \\
\hline AM & 48.8 & 1.6 & $69 \cdot 3$ & 1.8 & 87.0 & $1 \cdot 8$ & $15 \cdot 8$ & $1 \cdot 2$ & $18 \cdot 3$ & 1.3 & 20.4 & $1 \cdot 2$ \\
\hline $\mathrm{CM}$ & $44 \cdot 8$ & 0.6 & $65 \cdot 0$ & 0.8 & $82 \cdot 9$ & $1 \cdot 1$ & $10 \cdot 8$ & 0.9 & $13 \cdot 8$ & 0.9 & $16 \cdot 7$ & 0.9 \\
\hline \multicolumn{13}{|l|}{ Sucrose diet } \\
\hline AM & $46 \cdot 2$ & 0.7 & 65.9 & $1 \cdot 3$ & $84 \cdot 1$ & 1.6 & $16 \cdot 0$ & $1 \cdot 1$ & $19 \cdot 1$ & 1.3 & 21.9 & 1.5 \\
\hline $\mathrm{CM}$ & 43.5 & 0.3 & $63 \cdot 3$ & 0.5 & $81 \cdot 4$ & 0.4 & $11 \cdot 4$ & $1 \cdot 3$ & $14 \cdot 8$ & 1.6 & $18 \cdot 0$ & 1.8 \\
\hline \multicolumn{13}{|c|}{ Two-way ANOVA: $P$} \\
\hline Diet & \multicolumn{2}{|c|}{0.052} & \multicolumn{2}{|c|}{$0.042^{*}$} & \multicolumn{2}{|c|}{0.117} & \multicolumn{2}{|c|}{0.724} & \multicolumn{2}{|c|}{0.511} & \multicolumn{2}{|c|}{0.339} \\
\hline Milk & \multicolumn{2}{|c|}{$0.002^{*}$} & \multirow{2}{*}{\multicolumn{2}{|c|}{$\begin{array}{c}0.008^{*} \\
0.504\end{array}$}} & \multirow{2}{*}{\multicolumn{2}{|c|}{$\begin{array}{l}0.020^{*} \\
0.641\end{array}$}} & \multicolumn{2}{|c|}{$0.001^{*}$} & \multicolumn{2}{|c|}{$0.003^{*}$} & \multicolumn{2}{|c|}{$0.014^{*}$} \\
\hline Diet $\times$ milk & \multicolumn{2}{|c|}{0.057} & & & & & \multicolumn{2}{|c|}{0.847} & \multicolumn{2}{|c|}{0.947} & \multicolumn{2}{|c|}{0.932} \\
\hline
\end{tabular}

AM, artificial milk; CM, cows' milk.

* $P<0.05$.

†The postprandial blood glucose and insulin tolerance tests were performed on day 43 of the experimental diet administration. 

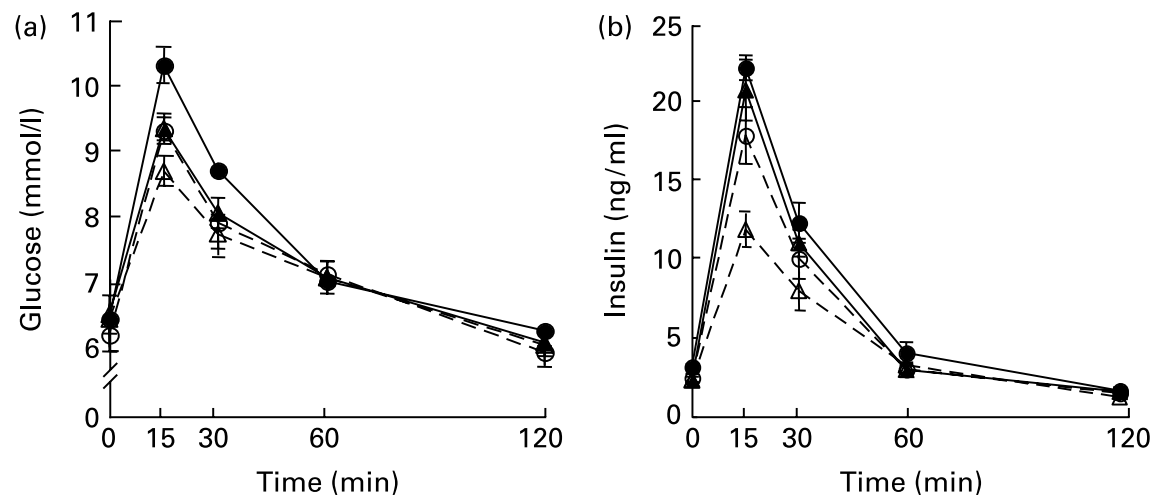

Fig. 2. Changes in serum glucose (a) and insulin (b) concentrations as determined by oral glucose tolerance tests (OGTT) in rats. (--O--), Dextrin-fed, artificial

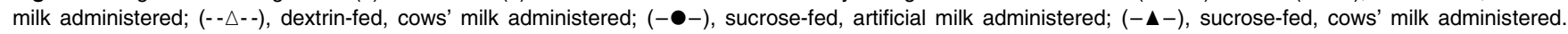
OGTT were performed on day 45 of the experimental diet. Values are means for six rats per group, with standard errors represented by vertical bars. $P$ values were estimated for peak values via two-way ANOVA: (a) 0 min serum glucose: diet, $P=0.071$; milk, $P=0.815$; diet $\times$ milk, $P=0.401 ; 15$ min serum glucose: diet, $P=0.003$; milk, $P=0.004$; diet $\times$ milk, $P=0.501$; (b) 0 min serum insulin: diet, $P=0.108$; milk, $P=0.034$; diet $\times$ milk, $P=0.150$; 15 min serum insulin: diet, $P<0.001$; milk, $P=0.021$; diet $\times$ milk, $P=0.137$.

using STATCEL2 (OMS, Saitama, Japan), which is an add-in application for Microsoft Excel (Redmond, WA, USA).

\section{Results}

Initial and final body weights, food intake and energy efficiencies did not differ among groups (data not shown).

\section{Postprandial serum glucose and insulin levels}

Postprandial serum glucose concentrations increased slowly until $60 \mathrm{~min}$ after feeding and then increased rapidly from 60-90 min in all four groups (Fig. 1(a)). The rats fed the D diet showed significantly higher peak serum glucose concentrations at $90 \mathrm{~min}$ compared with the $\mathrm{S}$-fed rats in both the CM-treated (D-CM, 11.31 (SEM 0.29) mmol/l v. S-CM, 10.21 (SEM 0.20) $\mathrm{mmol} / \mathrm{l}$ ) and AM-treated groups (D-AM, 13.30 (SEM 0.72) $\mathrm{mmol} / \mathrm{l}$ v. S-AM, 11.36 (SEM 0.30) $\mathrm{mmol} / \mathrm{l}$ ). Thereafter, serum glucose concentrations decreased gradually until $270 \mathrm{~min}$. Postprandial serum insulin concentrations peaked before postprandial glucose concentrations at $60 \mathrm{~min}$
(Fig. 1(b)). Peak values were significantly higher in the AM-treated groups than in the CM-treated groups for both the D- and S-fed rats.

AUC analysis (0-270 min) for both postprandial serum glucose and insulin showed significant differences between milk treatments $(P=0.020$ for glucose and $P=0.014$ for insulin; Table 3). The AUC for insulin was lower in the CM-treated groups than in the AM-treated groups.

\section{Oral glucose tolerance test}

No significant differences were observed in serum glucose concentrations among groups at $0 \mathrm{~min}$ (Fig. 2(a)). However, significant differences in serum insulin concentrations were detected at 0 min between the $\mathrm{CM}$ - and $\mathrm{AM}$-treated groups (two-way ANOVA; Fig. 2(b)). For all groups, serum glucose and insulin concentrations peaked $15 \mathrm{~min}$ after glucose administration and returned to basal levels within $120 \mathrm{~min}$. Two-way ANOVA revealed that peak glucose and insulin values at 15 min were influenced by both diet carbohydrate source and milk type $(P<0.05$; Fig. 2(a) and (b)). Peak serum glucose and insulin

Table 4. Area under the curve analysis for serum glucose and insulin concentrations in rats in response to oral glucose administration ( $2 \mathrm{~g} / \mathrm{kg}$ ) (Mean values with their standard errors for six rats per group)

\begin{tabular}{|c|c|c|c|c|c|c|c|c|c|c|c|c|}
\hline & \multicolumn{6}{|c|}{ Glucose $(\mathrm{mmol} / \mathrm{l})$} & \multicolumn{6}{|c|}{ Insulin (ng/ml) } \\
\hline & \multicolumn{2}{|c|}{$0-150 \min$} & \multicolumn{2}{|c|}{$0-60 \mathrm{~min}$} & \multicolumn{2}{|c|}{$0-120 \mathrm{~min}$} & \multicolumn{2}{|c|}{$0-150 \min$} & \multicolumn{2}{|c|}{$0-60 \min$} & \multicolumn{2}{|c|}{$0-120 \mathrm{~min}$} \\
\hline & Mean & SEM & Mean & SEM & Mean & SEM & Mean & SEM & Mean & SEM & Mean & SEM \\
\hline \multicolumn{13}{|l|}{ Dextrin diet } \\
\hline AM & $15 \cdot 5$ & 0.2 & 31.3 & 0.7 & 57.5 & $1 \cdot 2$ & 24.0 & $2 \cdot 0$ & 37.0 & $2 \cdot 6$ & 39.1 & 2.6 \\
\hline $\mathrm{CM}$ & 14.9 & 0.2 & $30 \cdot 4$ & 0.8 & $56 \cdot 7$ & 1.5 & $16 \cdot 9$ & 1.5 & $28 \cdot 0$ & 2.5 & $30 \cdot 2$ & $2 \cdot 5$ \\
\hline \multicolumn{13}{|l|}{ Sucrose diet } \\
\hline AM & $16 \cdot 1$ & 0.2 & 33.5 & 0.3 & $60 \cdot 1$ & 0.7 & 29.9 & 1.0 & $46 \cdot 1$ & $2 \cdot 4$ & 48.9 & $2 \cdot 7$ \\
\hline $\mathrm{CM}$ & $15 \cdot 4$ & 0.4 & 31.5 & 0.7 & 57.9 & $1 \cdot 2$ & $27 \cdot 4$ & $2 \cdot 3$ & $41 \cdot 3$ & 3.0 & 43.5 & 3.1 \\
\hline \multicolumn{13}{|c|}{ Two-way ANOVA: $P$} \\
\hline Diet & \multirow{2}{*}{\multicolumn{2}{|c|}{$\begin{array}{l}0.050^{*} \\
0.026^{*}\end{array}$}} & \multicolumn{2}{|c|}{$0.015^{*}$} & \multicolumn{2}{|c|}{$0 \cdot 117$} & \multicolumn{2}{|c|}{$<0.001^{*}$} & \multicolumn{2}{|c|}{$<0.001^{*}$} & \multicolumn{2}{|c|}{$<0.001^{*}$} \\
\hline Milk & & & \multirow{2}{*}{\multicolumn{2}{|c|}{$\begin{array}{l}0.029^{*} \\
0.417\end{array}$}} & \multirow{2}{*}{\multicolumn{2}{|c|}{$\begin{array}{l}0.208 \\
0.558\end{array}$}} & \multirow{2}{*}{\multicolumn{2}{|c|}{$0 \cdot 012^{*}$}} & \multirow{2}{*}{\multicolumn{2}{|c|}{$0 \cdot 017^{*}$}} & \multirow{2}{*}{\multicolumn{2}{|c|}{$0.016^{*}$}} \\
\hline Diet $\times$ milk & \multicolumn{2}{|c|}{0.873} & & & & & & & & & & \\
\hline
\end{tabular}

AM, artificial milk; CM, cows' milk.

${ }^{\star} P<0.05$. 
Table 5. Fasted serum TAG and fructosamine concentrations in rats $\dagger$ (Mean values with their standard errors for six rats per group)

\begin{tabular}{|c|c|c|c|c|}
\hline & \multicolumn{2}{|c|}{$\mathrm{TAG}(\mathrm{mmol} / \mathrm{l})$} & \multicolumn{2}{|c|}{$\begin{array}{l}\text { Fructosamine } \\
(\mu \mathrm{mol} / \mathrm{l})\end{array}$} \\
\hline & Mean & SEM & Mean & SEM \\
\hline \multicolumn{5}{|l|}{ Dextrin diet } \\
\hline AM & 1.3 & 0.1 & $136 \cdot 7$ & $6 \cdot 3$ \\
\hline $\mathrm{CM}$ & 1.4 & 0.1 & $120 \cdot 2$ & $4 \cdot 2$ \\
\hline \multicolumn{5}{|l|}{ Sucrose diet } \\
\hline AM & $2 \cdot 1$ & 0.1 & $152 \cdot 7$ & $15 \cdot 4$ \\
\hline $\mathrm{CM}$ & 1.9 & 0.2 & $122 \cdot 3$ & 3.9 \\
\hline \multicolumn{5}{|c|}{ Two-way ANOVA: $P$} \\
\hline Diet & $<0.001^{\star}$ & & 0.315 & \\
\hline Milk & 0.878 & & $0.015^{*}$ & \\
\hline Diet $\times$ milk & 0.426 & & 0.442 & \\
\hline
\end{tabular}

AM, artificial milk; CM, cows' milk.

${ }^{\star} P<0.05$.

†Tail blood from $8 \mathrm{~h}$ fasted rats was used to determine TAG concentrations on day 45. Abdominal aorta blood was used to determine fructosamine concentrations on day 49.

values were higher in the $\mathrm{S}$-fed rats than in the D-fed rats. In addition, peak serum glucose and insulin values were lower in the CM-treated groups than in the AM-treated groups.

In the OGTT, the AUC for serum glucose and insulin concentrations was calculated at $0-30 \mathrm{~min}, 0-60 \mathrm{~min}$ and 0-120 min (Table 4). Two-way ANOVA revealed that the AUC for insulin was higher in the S-fed rats than in the $\mathrm{D}$-fed rats, and lower in the CM-treated groups than in the AM-treated groups. Changes in serum glucose AUC were small but significant at $0-30 \mathrm{~min}$ and $0-60 \mathrm{~min}$, and the trends were similar to those observed for insulin. No interactions between diet and milk administration were observed for either insulin or glucose.

\section{Serum TAG and fructosamine concentrations}

Serum TAG concentrations were higher in the S-fed rats than in the D-fed rats (Table 5). CM administration did not significantly affect serum TAG concentrations compared with AM administration. Serum fructosamine concentrations were lower in the CM-treated groups than in the AM-treated groups, regardless of diet type (Table 5). Two-way ANOVA revealed a significant difference in serum fructosamine concentrations between the CM- and AM-treated rats $(P=0 \cdot 015)$.

\section{Weight of caecal contents and concentration of caecal organic acids}

Caecal content weights were higher in the CM-treated groups than in the AM-treated groups for both the D- and S-fed rats (Table 6). Total propionate per caecal content was higher in the CM-treated rats than in the AM-treated rats (Table 6). No significant differences were observed among groups in terms of the total molar weights of other organic acids.

\section{Caecal microbiota}

T-RFLP profiles generated by Hha I digestion are shown in Fig. 3(a)-(d). Peak X (209bp) was observed more frequently in the D-fed rats than in the S-fed rats, whereas peak Y (364 bp) appeared frequently in the S-fed rats, but not in the D-fed rats. Peak Z (641 bp) was almost uniquely observed in the CM-treated rats, regardless of diet type. After Msp I digestion, a unique peak $(163 \mathrm{bp})$ was also observed in the CM-treated rats (data not shown). According to a database generated using the MICA query function (http://mica.ibest. uidaho.edu/digest.php) and a BLAST search (http://blast. ncbi.nlm.nih.gov/Blast.cgi), 16S rRNA sequences from Phascolarctobacterium faecium (GenBank accession, X72865) showed restriction patterns of 641 and $163 \mathrm{bp}$ following Hha I and Msp I digestion, respectively. This bacterium is currently the only species known to show this restriction pattern when uncultured bacteria are excluded from the analysis.

After constructing a dendrogram based on T-RFLP patterns generated by Hha I digestion, two distinct clusters were observed (Fig. 4). All samples from the D-fed rats, with the exception of D-AM5, clustered into one area; the remaining samples (mostly from S-fed rats) clustered into another area. Within these distinct clusters, samples from the CM-treated rats grouped within the same cluster, whereas samples from the AM-treated rats grouped within a second cluster.

Table 6. Pools of organic acids in caecal contents from rats $\dagger$

(Mean values with their standard errors for six rats per group)

\begin{tabular}{|c|c|c|c|c|c|c|c|c|c|c|c|c|c|c|}
\hline & \multicolumn{2}{|c|}{$\begin{array}{l}\text { Succinate } \\
(\mu \mathrm{mol})\end{array}$} & \multicolumn{2}{|c|}{$\begin{array}{l}\text { Lactate } \\
(\mu \mathrm{mol})\end{array}$} & \multicolumn{2}{|c|}{$\begin{array}{c}\text { Acetate } \\
(\mu \mathrm{mol})\end{array}$} & \multicolumn{2}{|c|}{$\begin{array}{l}\text { Propionate } \\
\qquad(\mu \mathrm{mol})\end{array}$} & \multicolumn{2}{|c|}{$\begin{array}{c}n \text {-Butyrate } \\
(\mu \mathrm{mol})\end{array}$} & \multicolumn{2}{|c|}{$\begin{array}{l}\text { Total SCFA } \\
(\mu \mathrm{mol})\end{array}$} & \multicolumn{2}{|c|}{$\begin{array}{l}\text { Caecal } \\
\text { contents (g) }\end{array}$} \\
\hline & Mean & SEM & Mean & SEM & Mean & SEM & Mean & SEM & Mean & SEM & Mean & SEM & Mean & SEM \\
\hline \multicolumn{15}{|l|}{ Dextrin diet } \\
\hline AM & 1.0 & 0.5 & $2 \cdot 2$ & 0.7 & $53 \cdot 4$ & $5 \cdot 6$ & $19 \cdot 0$ & 1.9 & 11.3 & $2 \cdot 0$ & 83.7 & $9 \cdot 0$ & $2 \cdot 0$ & $0 \cdot 1$ \\
\hline $\mathrm{CM}$ & 1.5 & $1 \cdot 0$ & $3 \cdot 0$ & $1 \cdot 3$ & $65 \cdot 1$ & $6 \cdot 1$ & $28 \cdot 1$ & $4 \cdot 0$ & $5 \cdot 8$ & 0.6 & 99.4 & $9 \cdot 0$ & 3.3 & 0.2 \\
\hline \multicolumn{15}{|l|}{ Sucrose diet } \\
\hline AM & 8.6 & 4.5 & 3.0 & 0.9 & $42 \cdot 4$ & 4.8 & $15 \cdot 5$ & $1 \cdot 7$ & 7.5 & $2 \cdot 1$ & 65.5 & $8 \cdot 0$ & $2 \cdot 0$ & 0.2 \\
\hline $\mathrm{CM}$ & $3 \cdot 3$ & $3 \cdot 0$ & $2 \cdot 7$ & $1 \cdot 7$ & $50 \cdot 9$ & $5 \cdot 9$ & $21 \cdot 4$ & $2 \cdot 6$ & $7 \cdot 9$ & 3.5 & $80 \cdot 2$ & $6 \cdot 9$ & $2 \cdot 8$ & 0.2 \\
\hline \multicolumn{15}{|c|}{ Two-way ANOVA: $P$} \\
\hline Diet & \multicolumn{2}{|c|}{0.100} & \multicolumn{2}{|c|}{0.855} & \multicolumn{2}{|c|}{$0.033^{\star}$} & \multicolumn{2}{|c|}{0.071} & \multicolumn{2}{|c|}{0.718} & \multicolumn{2}{|c|}{$0.034^{*}$} & \multicolumn{2}{|c|}{0.096} \\
\hline Milk & \multicolumn{2}{|c|}{0.384} & \multirow{2}{*}{\multicolumn{2}{|c|}{$\begin{array}{l}0.846 \\
0.666\end{array}$}} & \multirow{2}{*}{\multicolumn{2}{|c|}{$\begin{array}{l}0.082 \\
0.748\end{array}$}} & \multirow{2}{*}{\multicolumn{2}{|c|}{$\begin{array}{l}0.011^{\star} \\
0.547\end{array}$}} & \multicolumn{2}{|c|}{0.286} & \multicolumn{2}{|c|}{0.079} & \multicolumn{2}{|c|}{$<0.001^{*}$} \\
\hline Diet $\times$ milk & \multicolumn{2}{|c|}{0.299} & & & & & & & \multicolumn{2}{|c|}{0.211} & \multicolumn{2}{|c|}{0.953} & \multicolumn{2}{|c|}{$0 \cdot 168$} \\
\hline
\end{tabular}

AM, artificial milk; CM, cows' milk.

${ }^{*} P<0.05$.

†Total SCFA $=$ sum of acetate, propionate and $n$-butyrate concentrations. Caecal contents were used to determine pools of organic acids on day 49. 
The only exception was S-AM6, which grouped with samples from the CM-treated rats. The dendrogram constructed from T-RFLP patterns generated by Ms I digestion showed very similar clustering (data not shown).

Expression of $\mathrm{Na}^{+}$-dependent glucose transporter-1, glucose transporter-2 and proglucagon in the small intestine

No significant differences were observed among groups in terms of SGLT1 or proglucagon mRNA expression in the duodenum, jejunum or ileum (data not shown). However, a significant difference among groups was detected for GLUT2 mRNA expression in the duodenum, although no significant differences were detected regarding jejunal or ileal GLUT2 mRNA levels. Regardless of diet type, the CM-treated

(a)
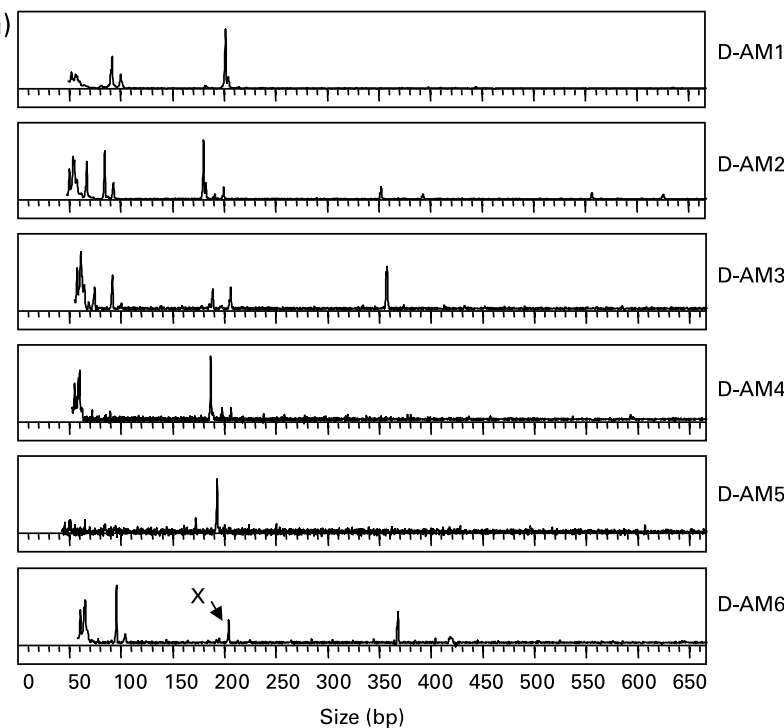

(c)
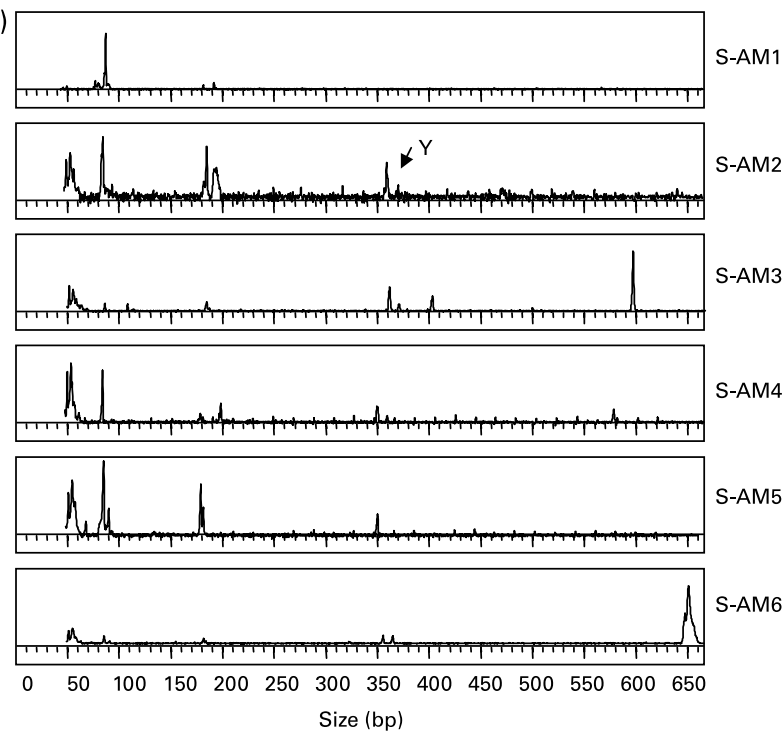

rats showed lower GLUT2 mRNA expression in the duodenum compared with the AM-treated rats. The CM-treated rats showed a $20 \%$ decrease in GLUT2 transcription compared with the diet-matched AM-treated rats (Fig. 5).

\section{Discussion}

No previous animal study has demonstrated the effects of long-term daily $\mathrm{CM}$ consumption on insulin sensitivity using reasonable doses of $\mathrm{CM}$. We conducted these studies using rats, which allowed for the strict control of diet composition and feeding time. We demonstrated that CM improves insulin sensitivity, as determined via the OGTT, in rats fed either a D- or S-based diet. As we hypothesised, improvement of insulin sensitivity by CM was achieved with a reasonable

(b)
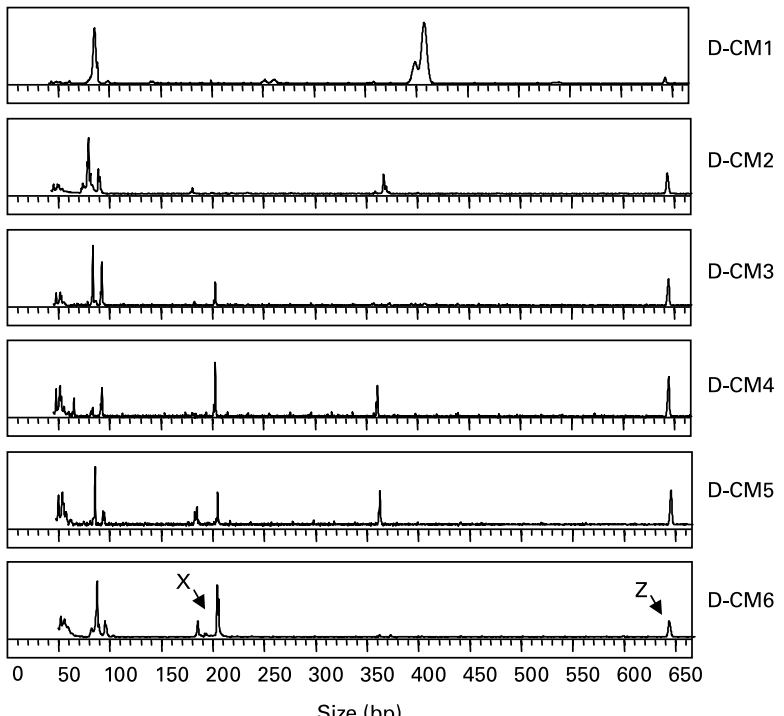

(d)
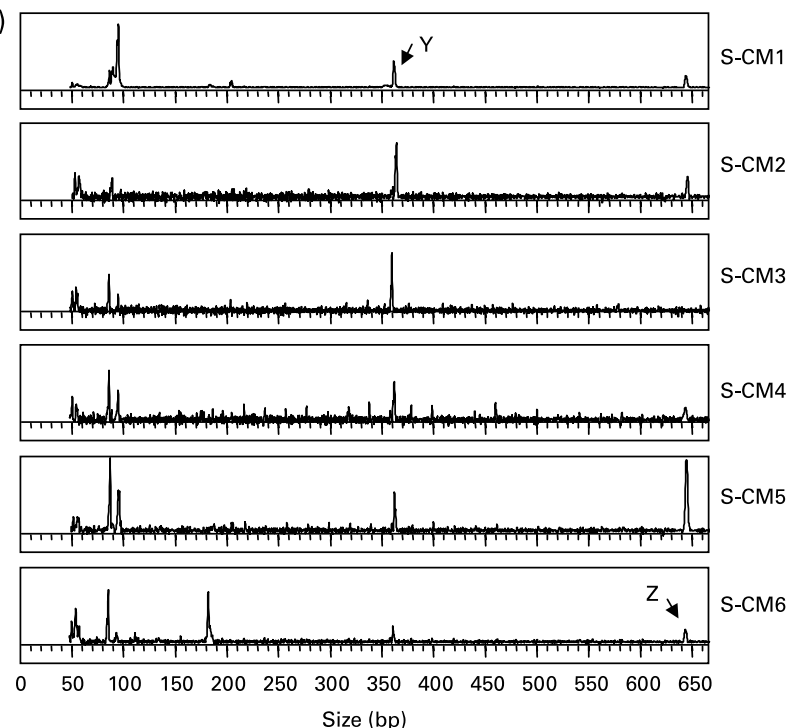

Fig. 3. Terminal-restriction fragment length polymorphism profiles representing caecal bacterial diversity in rats administered cows' milk (CM) or artificial milk (AM) while on a dextrin (D)- $(a$ and $b)$ or a sucrose (S)-based diet (c and d). Peak $X(209 \mathrm{bp})$ was observed more frequently in the D- $v$. S-fed rats, whereas peak $Y$ (364 bp) appeared frequently in the S-fed rats, but not in the D-fed rats. Peak Z (641 bp) was almost uniquely observed in the CM-treated rats, regardless of diet type. Each profile is for a sample from an individual rat (six rats per group). 


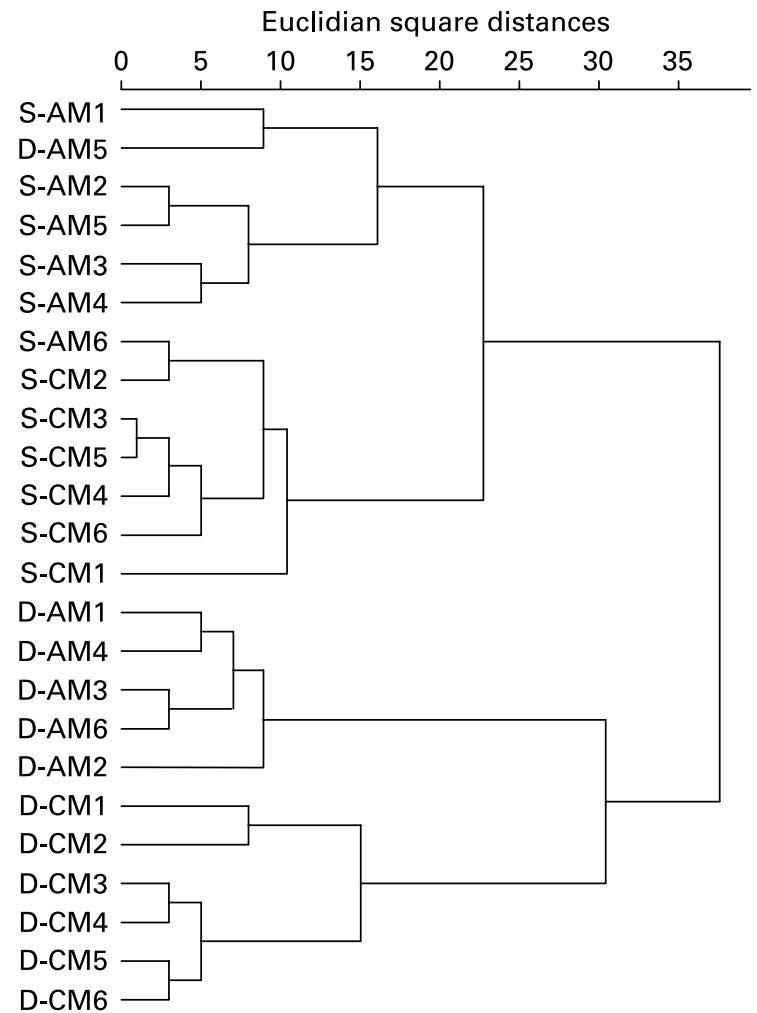

Fig. 4. Dendrogram based on the terminal-restriction fragment length polymorphism profiles generated using a hierarchical clustering analysis with Euclidean square distances. D-AM, dextrin-fed, artificial milk administered; D-CM, dextrin-fed, cows' milk administered; S-AM, sucrose-fed, artificial milk administered; S-CM, sucrose-fed, cows' milk administered. Each line relates to a sample from an individual rat (six rats per group).

dose of $\mathrm{CM}$ and without any replacement of the main ingredients in the diet by $\mathrm{CM}$ in a rat model. Rats fed the high-S diet showed insulin resistance; however, CM treatment improved insulin sensitivity, as evidenced by lower fasting and postprandial insulin levels and lower serum fructosamine concentrations compared with the AM-treated rats. This reduction in serum fructosamine suggests that decreased insulin resistance within the $\mathrm{CM}$ groups may have been observed at least a few weeks before dissection ${ }^{(40,41)}$.

According to the $\mathrm{FAO}^{(1)}$, the yearly per capita consumption of CM was $81 \mathrm{~kg}$ in 2003, which corresponds to approximately $220 \mathrm{ml} / \mathrm{d}$. In addition, humans obtain approximately $628 \mathrm{~kJ}$ per $\mathrm{d}$ from $\mathrm{CM}$ and related products, which accounts for approximately $6-8 \%$ of total daily energy consumption (8360$10460 \mathrm{~kJ} / \mathrm{d}$ ). In a preliminary experiment, Fisher 344 rats weighing about $200 \mathrm{~g}$ consumed approximately $209 \mathrm{~kJ} / \mathrm{d}$ on a voluntary basis. For this reason, $5 \mathrm{ml} / 200 \mathrm{~g}$ body weight $(14 \cdot 2 \mathrm{~kJ} / 200 \mathrm{~g}$ body weight) was selected as a 'normal' daily dose of CM.

For the present study, we prepared AM to have a nutritional composition close to that of $\mathrm{CM}$ and to have no or fewer effects on insulin resistance. The egg white protein was used because its amino acid score is equal to that of CM. Although both maltose and sucrose are disaccharides, as is lactose, it is known that sucrose clearly affects insulin sensitivity ${ }^{(42)}$. Thus the former was used. The main fatty composition of lard, such as oleic acid, is close to that $\mathrm{CM}^{(31)}$. Indeed, the AM-treated rats in the D-fed group showed almost the same concentrations of blood insulin and glucose as rats fed only a D diet in other reports $^{(43,44)}$. Thus it is suggested that the AM used in the present study might have almost no effects on insulin sensitivity.

No significant interactions were observed between the test diet and test milk in the OGTT and other evaluations, demonstrating that the effects of CM do not depend upon dietary carbohydrate source. These results suggest that CM not only improves insulin resistance in animals with the metabolic syndrome but also suppresses the progression of the metabolic syndrome with glucose intolerance.

Regarding the mechanism of reduced insulin sensitivity, two interesting results were obtained in the present study. The first is that duodenal GLUT2 mRNA expression decreased significantly in the CM-treated rats compared with the AMtreated rats. Second, caecal microbiota SCFA composition profiles differed markedly between the CM- and AM-treated rats.

GLUT2 is normally expressed in both the apical and basolateral membranes of intestinal epithelial cells and is responsible for approximately $60 \%$ of small-intestinal glucose uptake $^{(45)}$. Decreased GLUT2 expression after CM administration was observed only in the duodenum, not in the jejunum or ileum. Therefore, the impact of CM administration on small-intestinal glucose absorption may not be drastic. However, a $20 \%$ reduction in duodenal GLUT2 mRNA expression after CM consumption may slow glucose absorption within the small intestine, which may underlie the observed improvement in insulin sensitivity. Because CM administration showed no effect on SGLT1 or proglucagon mRNA expression in the small intestine, SGLT1 and glucagon-like peptide-1 may not be involved in CM-reduced insulin sensitivity.

The characteristic T-RFLP peaks observed in the CM-administered rats matched the restriction patterns for $16 \mathrm{~S}$ rRNA genes in $P$. faecium, which is reported to produce propionate $^{(46,47)}$. Indeed, propionate concentrations within caecal

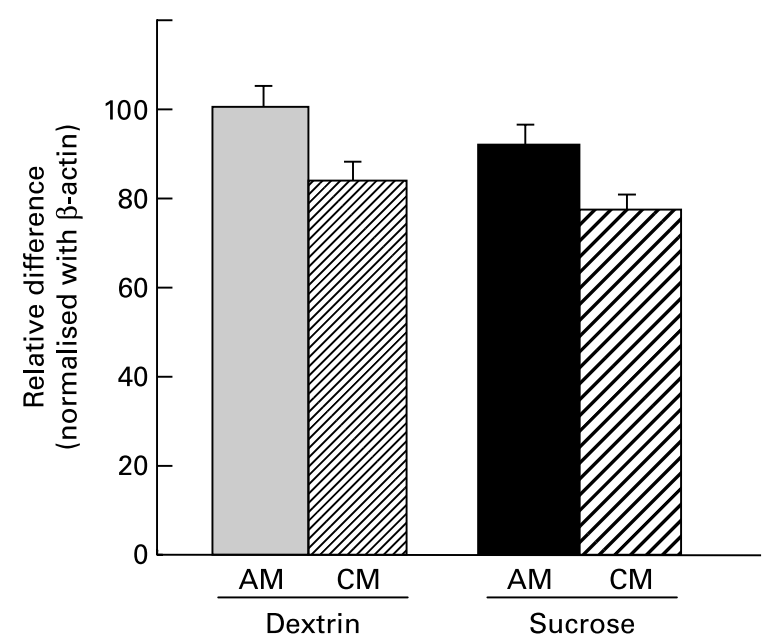

Fig. 5. Duodenal GLUT2 mRNA expression in rats administered cows' milk (CM) or artificial milk (AM) while on a dextrin (D)- or a sucrose-based diet. The arbitrary units for GLUT2 expression were normalised against $\beta$-actin expression and subjected to statistical analysis. Data are presented as relative differences when the value of D-AM $=100 \%$. Values are means for six rats per group, with standard errors represented by vertical bars. Results of the statistical analyses (two-way ANOVA) are: diet, $P=0.262$; milk, $P=0.027$; diet $\times$ milk, $P=0.876$. 
contents increased significantly in the CM-administered rats. It has been demonstrated in experimental animals that alterations in intestinal microbiota have a marked impact on insulin resistance ${ }^{(25,26)}$. Furthermore, in a double-blind human study, it was suggested that the oral administration of a propionatecontaining capsule for 7 weeks significantly improved insulin resistance ${ }^{(48)}$. Therefore, alterations in intestinal microbiota and SCFA profiles may represent a second explanation for the regulatory effects of long-term daily $\mathrm{CM}$ administration on insulin resistance.

T-RFLP was used in the present study to reveal the compositional difference in caecal microbiota among the experimental groups. However, T-RFLP is less suitable for the quantification of a specific bacterial population compared with fluorescent in situ hybridisation- and real-time PCRbased analyses of intestinal microbiota ${ }^{(49)}$. Thus investigation of the effects of CM on intestinal microbiota using these techniques should be further conducted in the future.

$\mathrm{CM}$ is an emulsion that consists of lactose, milk-fat, casein, whey protein, minerals (for example, $\mathrm{K}$ and $\mathrm{Ca}$ ) and other components (for example, peptides and oligosaccharides $)^{(31-34)}$. It remains unclear which components of CM are responsible for the observed improvement in insulin resistance. Because the AM formula used here contained the same amount of $\mathrm{Ca}$ as $\mathrm{CM}$, it is unlikely that $\mathrm{Ca}$ is involved in regulating insulin resistance. Instead, lactose and oligosaccharides may be responsible for the observed alterations in the caecal environment and improved insulin sensitivity in the CM-treated rats. Whey protein may also be an important factor in improved insulin resistance, including the reduction of the duodenal GLUT2 expression. Considering these results, the beneficial effects of $\mathrm{CM}$ on insulin resistance may be the result of multiple factors.

In conclusion, the present results demonstrate that longterm daily $\mathrm{CM}$ administration improves insulin resistance induced by a high-S diet. In addition, CM improves insulin sensitivity in normal rats, lowers small-intestinal glucose uptake via the suppression of GLUT2 expression and alters the large-intestinal environment. These factors may contribute to the observed beneficial effects of daily CM consumption. To our knowledge, the present study is the first to demonstrate improved insulin sensitivity after long-term daily CM ingestion in an animal model. The present results suggest that $\mathrm{CM}$ is effective in counteracting the metabolic syndrome, even at reasonable concentrations.

\section{Acknowledgements}

A part of the present study was supported by Japan Dairy Association. The authors would like to thank Mr T. Mochida, $\mathrm{Mr}$ I. Nojima, Ms A. Shinoki, Mr M. Hagio and Ms N. Matsukawa at the Graduate School of Agriculture (Hokkaido University) for their assistance with the animal experiments. We are also grateful to Ms Y. Kuzuma and Mr S. Hioki (Field Science Centre for Northern Biosphere, Hokkaido University), Dr K. Shimazaki (Graduate School of Agriculture, Hokkaido University) and Dr M. Yajima (Creative Research Initiative Sousei, Hokkaido University) for their assistance with the preparation of the AM.
All authors contributed to the preparation of the paper and agreed with the submitted content.

There are no conflicts of interest.

\section{References}

1. Food and Agriculture Organization (2008) Food Security Statistics. http://www.fao.org/faostat/foodsecurity/index_en.htm

2. Mirmiran P, Esmaillzadeh A \& Azizi F (2005) Dairy consumption and body mass index: an inverse relationship. Int J Obes $\mathbf{2 9}$, $115-121$.

3. Zemel MB, Shi H, Greer B, et al. (2000) Regulation of adiposity by dietary calcium. FASEB $J \mathbf{1 4}, 1132-1138$.

4. Carruth BR \& Skinner JD (2001) The role of dietary calcium and other nutrients in moderating body fat in preschool children. Int J Obes Relat Metab Disord 25, 559-566.

5. Moore LL, Bradlee ML, Gao D, et al. (2006) Low dairy intake in early childhood predicts excess body fat gain. Obesity 14, 1010-1018.

6. Choi HK, Willett WC, Stampfer MJ, et al. (2005) Dairy consumption and risk of type 2 diabetes mellitus in men: a prospective study. Arch Intern Med 165, 997-1003.

7. Liu S, Choi HK \& Ford E (2006) A prospective study of dairy intake and the risk of type 2 diabetes in women. Diabetes Care 29, 1579-1584.

8. Pereira MA, Jacobs DR Jr, Van Horn L, et al. (2002) Dairy consumption, obesity, and the insulin resistance syndrome in young adults: the CARDIA Study. JAMA 287, 2081-2089.

9. Belobrajdic D, McIntosh G \& Owens J (2003) The effects of dietary protein on rat growth, body composition and insulin sensitivity. Asia Pac J Clin Nutr 2, S42.

10. Zemel MB \& Sun X (2008) Dietary calcium and dairy products modulate oxidative and inflammatory stress in mice and humans. J Nutr 138, 1047-1052.

11. Parra P, Bruni G, Palou A, et al. (2008) Dietary calcium attenuation of body fat gain during high-fat feeding in mice. $J$ Nutr Biochem 19, 109-117.

12. Pichon L, Potier M, Tome D, et al. (2008) High-protein diets containing different milk protein fractions differently influence energy intake and adiposity in the rat. Br J Nutr 99, 739-748.

13. Mokdad AH, Ford ES, Bowman BA, et al. (2003) Prevalence of obesity, diabetes, and obesity-related health risk factors, 2001. JAMA 28, 76-79.

14. O'Keefe JH \& Bell DS (2007) Postprandial hyperglycemia/ hyperlipidemia (postprandial dysmetabolism) is a cardiovascular risk factor. Am J Cardiol 100, 899-904.

15. Gomez Dumm CL (1996) Long-term administration of a sucrose-rich diet to normal rats: relationship between metabolic and hormonal profiles and morphological changes in the endocrine pancreas. Metabolism 45, 1527-1532.

16. Oliart Ros RM, Torres-Márquez ME, Badillo A, et al. (2001) Dietary fatty acids effects on sucrose-induced cardiovascular syndrome in rats. $J$ Nutr Biochem 12, 207-212.

17. Thomson AB \& Wild G (1997) Adaptation of intestinal nutrient transport in health and disease. Dig Dis Sci 42, 453-469.

18. Tandon RK, Srivastava LM \& Pandey SC (1975) Increased disaccharidase activity in human diabetics. Am J Clin Nutr 28, $621-625$.

19. Marks J, Carvou NJ, Debnam ES, et al. (2003) Diabetes increases facilitative glucose uptake and GLUT2 expression at the rat proximal tubule brush border membrane. J Physiol 553, 137-145.

20. Richardson M, Affleck J \& Kellett GL (2000) Regulation of GLUT5, GLUT2 and intestinal brush-border fructose absorption by the extracellular signal-regulated kinase, p38 mitogenactivated kinase and phosphatidylinositol 3-kinase intracellular 
signaling pathways: implications for adaptation to diabetes. Biochem J 15, 163-169.

21. Corpe CP, Basaleh MM, Affleck J, et al. (1996) The regulation of GLUT5 and GLUT2 activity in the adaptation of intestinal brushborder fructose transport in diabetes. Pflugers Arch 432, 192-201.

22. Palnaes Hansen C, Andreasen JJ \& Holst JJ (1997) The release of gastric inhibitory peptide, glucagon-like peptide-I, and insulin after oral glucose test in colectomized subjects. Scand J Gastroenterol 32, 473-477.

23. Printz H, Reiter S, Samadi N, et al. (1998) GLP-1 release in man after lower large bowel resection or intrarectal glucose administration. Digestion 59, 689-695.

24. Bäckhed F, Ding H, Wang T, et al. (2004) The gut microbiota as an environmental factor that regulates fat storage. Proc Natl Acad Sci U S A 101, 15718-15723.

25. Dumas ME, Barton RH, Toye A, et al. (2006) Metabolic profiling reveals a contribution of gut microbiota to fatty liver phenotype in insulin-resistant mice. Proc Natl Acad Sci U S A 15, 12511-12516.

26. Cani PD, Amar J, Iglesias MA, et al. (2007) Metabolic endotoxemia initiates obesity and insulin resistance. Diabetes 56, 1761-1772.

27. Anderson JW \& Bridges SR (1984) Short-chain fatty acid fermentation products of plant fiber affect glucose metabolism of isolated rat hepatocytes. Proc Soc Exp Biol Med 177, 372-376.

28. Robertson M (2007) Metabolic cross talk between the colon and the periphery: implications for insulin sensitivity. Proc Nutr Soc 66, 351-361.

29. Reeves PG, Nielsen FH \& Fahey GC Jr (1993) AIN-93 purified diets for laboratory rodents: final report of the American Institute of Nutrition ad hoc writing committee on the reformulation of the AIN-76A rodent diet. $J$ Nutr 123, 1939-1951.

30. Yajima M, Kanno T \& Yajima T (2006) A chemically derived milk substitute that is compatible with mouse milk for artificial rearing of mouse pups. Exp Anim 55, 391-397.

31. Science and Technology Agency (2005) Standard Tables of Food Composition in Japan, fifth revised and enlarged ed. Tokyo: Kagawa Nutrition University Publishing Division.

32. Walstra P (1979) The voluminosity of bovine casein micelles and some of its implications. J Dairy Res 46, 317-323.

33. Gopal PK \& Gill HS (2002) Oligosaccharides and glycoconjugates in bovine milk and colostrum. Br J Nutr 84, Suppl. 1, S69-S74.

34. Christie WW (1995) Composition and structure of milk lipids. In Advanced Dairy Chemistry-2, Lipids, pp. 1-36 [PF Fox, editor]. London: Chapman \& Hall.

35. Inoue R, Otsuka M, Nishio A, et al. (2007) Primary administration of Lactobacillus johnsonii NCC533 in weaning period suppresses the elevation of proinflammatory cytokines and CD86 gene expressions in skin lesions in $\mathrm{NC} / \mathrm{Nga}$ mice. FEMS Immunol Med Microbiol 50, 67-76.
36. Inoue R, Tsuruta T, Nojima I, et al. (2008) Postnatal changes in the expression of genes for cryptdins $1-6$ and the role of luminal bacteria in cryptdin gene expression in mouse small intestine. FEMS Immunol Med Microbiol 52, 407-416.

37. Countway PD, Gast RJ, Savai P, et al. (2005) Protistan diversity estimates based on 18S rDNA from seawater incubations in the Western North Atlantic. $J$ Eukaryot Microbiol 52 , 95-106.

38. Inoue R \& Ushida K (2003) Development of the intestinal microbiota in rats and possible interactions with the evolution of the luminal IgA in the intestine. FEMS Microbiol Ecol 45, $147-153$.

39. Shiga K, Hara H, Okano G, et al. (2003) Ingestion of watersoluble soybean fiber prevents gastrectomy-induced iron malabsorption, anemia and impairment of voluntary running exercise performance in rats. J Nutr 133, 1120-1126.

40. Woerle HJ, Neumann C, Zschau S, et al. (2007) Impact of fasting and postprandial glycemia on overall glycemic control in type 2 diabetes: importance of postprandial glycemia to achieve target HbA1c levels. Diabetes Res Clin Pract 77, 280-285.

41. Monnier VM, Sell DR, Dai Z, et al. (2008) The role of the amadori product in the complications of diabetes. Ann $N Y$ Acad Sci 1126, 81-88.

42. Häberer D, Thibault L, Langhans W, et al. (2009) Beneficial effects on glucose metabolism of chronic feeding of isomaltulose versus sucrose in rats. Ann Nutr Metab 54, 75-82.

43. Damiano PF, Rosón MI, Armando I, et al. (1999) Potential role of glycerol leading to rat fructose hypertension. Hypertension 34, 1007-1011.

44. Suzuki T \& Hara H (2004) Ingestion of guar gum hydrolysate, a soluble and fermentable nondigestible saccharide, improves glucose intolerance and prevents hypertriglyceridemia in rats fed fructose. J Nutr 134, 1942-1947.

45. Gouyon F, Caillaud L, Carriere V, et al. (2003) Simple-sugar meals target GLUT2 at enterocyte apical membranes to improve sugar absorption: a study in GLUT2-null mice. $J$ Physiol 552, $823-832$

46. Janssen PH \& O'Farrell KA (1999) Succinispira mobilis gen. nov., sp. nov., a succinate-decarboxylating anaerobic bacterium. Int J Syst Bacteriol 3, 1009-1013.

47. van Gylswyk NO, Hippe H \& Rainey FA (1997) Schwartzia succinivorans gen. nov., sp. nov., another ruminal bacterium utilizing succinate as the sole energy source. Int J Syst Bacteriol 47, 155-159.

48. Venter CS, Vorster HH \& Cummings JH (1990) Effects of dietary propionate on carbohydrate and lipid metabolism in healthy volunteers. Am J Gastroenterol 85, 549-553.

49. Zoetendal EG, Collier CT, Koike S, et al. (2004) Molecular ecological analysis of the gastrointestinal microbiota. J Nutr 134, 465-472. 